\title{
CHANGES IN LEAF TISSUES OF COMMON HORSE CHESTNUT (Aesculus hippocastanum L.) COLONISED BY THE HORSE-CHESTNUT LEAF MINER (Cameraria ochridella Deschka\&Dimić)
}

\author{
Elżbieta Weryszko-Chmielewska, Weronika Haratym \\ Department of Botany, University of Life Sciences in Lublin, Akademicka 15, 20-950 Lublin, Poland \\ e-mail: elzbieta.weryszko@up.lublin.pl
}

Received: 05.10.2011

\begin{abstract}
The present study, conducted during the period 20102011, involved morphological observations and anatomical investigations of horse chestnut (Aesculus hippocastanum L.) leaves with symptoms of damage caused by feeding of larvae of the horse-chestnut leaf miner (Cameraria ohridella Deschka\&Dimić). Leaves were collected from trees growing in the city of Lublin (Poland). Microscopic slides were prepared from fresh and fixed plant material. Leaf anatomical features were examined by light microscopy in order to determine the mechanical barrier for feeding pests. Changes were also observed during the progressive damage of the leaf tissues caused by the larvae. Selected developmental stages of the pest are presented in the paper. It has been shown that very thin blades of the mesomorphic leaves of Aesculus hippocastanum produce a poorly-developed mechanical barrier in which the following elements can be included: the presence of collenchyma and idioblasts with druses of calcium oxalate, few non-glandular trichomes found close to the leaf veins as well as relatively thin outer walls of the epidermal cells. The cells containing tannins and the oil cells found in the mesophyll may form a physiological barrier. However, foraging leaf miner larvae feed only on the palisade and spongy parenchyma cells, leaving undamaged the cells with tannins as well as the idioblasts with calcium oxalate crystals and oils. The feeding of the pest in the leaf mesophyll leads to the death of the epidermis on both sides of the lamina and to drying of the parts of the leaves in the area of the mines.
\end{abstract}

Key words: Aesculus hippocastanum, leaf, tissues, mechanical barrier, physiological barrier, larvae feeding, Cameraria ohridella

\section{INTRODUCTION}

Common horse chestnut (Aesculus hippocastanum L.) is an ornamental tree that is frequently planted in Poland and in other European countries ( $\mathrm{S}$ e $\mathrm{n}$ e $\mathrm{ta}$ and Dolatowski, 2007). It also belongs to melliferous (Li piński, 2010), medicinal (Podbie lkowski, 1992; Strzelecka and Kowalski, 2000), and cosmetic plants (J ę d r z e j k o et al. 2007). Horse chestnut bark, leaves, flowers, and seeds are used as medicinal raw material (Kohlmún zer, 1998). The leaves contain flavonoids, coumarins, phenolic acids, tannins, and saponins. The compounds contained in the tissues of horse chestnut counteract, among others, inflammatory conditions and venous stasis (Antkowiak, 1998; Strzelecka and K o w a l s k i , 2000). Common horse chestnut also belongs to poisonous plants due to the content of triterpene saponins. Horse chestnut seeds have been a cause of fatal poisoning in humans ( $\mathrm{S}$ a d o w s k a , 2004). Glue is produced from its seeds rich in starch. They are also used as animal fodder. Horse chestnut wood is used to produce furniture and cellulose (P o d bi e $1 \mathrm{kow} \mathrm{s} \mathrm{ki}$ and S u dnik-W ój cikowska, 2003).

Damage on horse chestnut leaves caused by feeding of the horse-chestnut leaf miner (Cameraria ohridella Deschka\&Dimić) has been observed in Poland since 1998 ( Eabanowski and Soika, 1998). Resistance to low temperatures, the low activity of parasitoids, and the possibility of insects being transported by the wind promote the spread of this pest ( $\mathrm{E}$ a b a n o w s k i , 2003). Due to the small dimensions of this insect, it can be part of the aeroplankton carried by air currents.

The biology of development of the horse-chestnut leaf miner has been studied in Poland $(\mathrm{K} \mathrm{u} \mathrm{k} \mathrm{u} 1$ a et al. 2002, B a ranow ski et al. 2002, 2004; Ła b a n o w s ki , 2003) and in many European countries 
(S k uhravy, 1999; Grabenwe ge r, 2003; N a rdini et al. 2004; Grabenwe ger et al. 2005).

Research on the development of effective methods to control this pest has been ongoing for more than a dozen years (Feemers, 1997; Krehan, 1997; Kukuła et al. 2002; Łabanowski et al. 2004; Kosibowicz, 2005; Głowacka et al. 2009).

The aim of the present study was to show the anatomical features of the leaves of common horse chestnut which promote feeding of horse-chestnut leaf miner larvae as well as to evaluate the mechanical and physiological barriers to phytophagous leaf-mining insects which can be formed by the leaf tissues of this species.

\section{MATERIALS AND METHODS}

Anatomical investigations of the leaves of common horse chestnut (Aesculus hippocastanum L.) were conducted in the years 2010 and 2011. Material for examination was collected from trees growing in the city centre of Lublin $\left(\varphi 22^{\circ} 34^{\prime} \mathrm{E}, \lambda 51^{\circ} 14^{\prime} \mathrm{N}\right)$.

Stereoscopic and light microscopy was used. Healthy pieces and the parts colonised by the horse-chestnut leaf miner were cut off from fresh leaves and cross sections of the leaf blade and of the midrib were prepared with a manual microtome using a scalpel or blade.

Histochemical tests were used to detect essential oils (Sudan III solution) and starch (JKJ). Part of the plant material was fixed in $70 \%$ ethanol and slides of leaf cross sections were also prepared. The thickness of leaf blades, midrib, palisade and spongy parenchyma, and epidermis was measured in 10-15 leaves. In the places where mines occurred, the leaf tissues were also viewed on the microscopic slides from the adaxial and abaxial side of the epidermis. Healthy and damaged leaf tissues as well as different instars of $\mathrm{Ca}$ meraria ohridella were observed and photographed.

\section{RESULTS}

\section{Anatomical features of the leaf}

Midrib

The thickness of the midrib of the horse chestnut leaf was from $193,7 \mu \mathrm{m}$ to $2158 \mu \mathrm{m}$ on avarage $907 \mu \mathrm{m}$. In cross-sectional view, different sized cells can be seen in the epidermis. In the abaxial (lower) part of the epidermis, the cells are much smaller than in the adaxial (upper) part (Fig. 1a). The outer thickened wall of the adaxial epidermis is covered by a cuticle showing distinct striation (Fig. 1b). Some cells of this tissue contain vacuoles with tannins. In the subepidermal layer of the upper part of the midrib, chlorenchyma is found; it is composed of 3-5 tiers of cells and is separated by sclerenchymatous tissue (Fig. 1b).

Long non-glandular hairs are found in the lower epidermis of the midrib (Fig. 2i). Tangential collenchyma, composed of 1-2 layers of cells, is the subepidermal tissue of the abaxial part of the leaf vein. The parenchymatous tissue (2-4 layers) is located beneath the collenchyma. The cells of this tissue contain few chloroplasts. Some cells of this layer are crystal-bearing idioblasts, forming different sized druses of calcium oxalate (Fig. $1 \mathrm{c}-\mathrm{g}$ ). These cells form multiple row lines running along the leaf vein (Fig. 1c).

The vascular bundle, occupying the central part of the midrib, is surrounded by a layer of sclerenchyma consisting of 2-4 rows of cells (Fig. 1a,d). The cell walls of some vessels, notably some phloem elements and also of the parenchyma locally, have a brown colouring, probably resulting from tannin impregnation (Fig. 1a,b,g).

\section{Leaf blade}

The average thickness of the leaf blade of common horse chestnut is $105 \mu \mathrm{m}$. The height of the adaxial epidermal cells is on average $17 \mu \mathrm{m}$. When viewed from above, they are polygonal shaped (Fig. 2f). The outer walls of these cells have a thickness of ca. 1.3 $\mu \mathrm{m}$ and are covered with a striated cuticle (Fig. 2a,c,e). Some cells of the adaxial epidermis contain brown coloured vacuoles, which may be attributable to the presence of tannins (Fig. 2 c, e, f).

The palisade parenchyma is composed of one layer of cylindrical cells with a length of ca. $32 \mu \mathrm{m}$, containing numerous chloroplasts (Fig. 2a,b,c). Several layers of loosely arranged cells can be distinguished in the spongy parenchyma (Fig. 2a,b). The thickness of the spongy parenchyma layer is on average 39 $\mu \mathrm{m}$. When viewed from the bottom side of the leaf, this tissue is characterized by the presence of a system of regularly distributed large intercellular spaces (Fig. 2d). Numerous chloroplasts occurred in the cells of both types of mesophyll; after the chloroplasts were treated with JKJ solution, dark blue grains of assimilation starch could be seen in these cells.

The crystal-bearing idioblasts are located beneath the vascular bundles in the subepidermal layer. In the vicinity of the vascular bundles, these cells form variably sized clusters (Fig. 2a). But most frequently they occur singly in the palisade or spongy parenchyma of the interbundle (intercostal) regions (Fig. 2d). The aggregates of calcium oxalate crystals (druses) that are found in the vacuoles of these idioblasts are characterized by massive spines and they occupy a major part of the volume of the cells. 
Another type of idioblast-like cells was observed between the cells of the palisade and spongy parenchyma. These cells were marked by very large dimensions $(32-48 \mu \mathrm{m})$, a thick wall, and the colourless contents of the vacuoles (Fig. 2c). They occurred singly or in groups of 2-3 (Fig. 5f). The application of Sudan III resulted in red-orange staining of the vacuole, which may be evidence of the presence of oils.

The lower (abaxial) epidermis of the leaf surface, ca. $12 \mu \mathrm{m}$ thick, is composed of cells with strongly undulating anticlinal walls (Fig. 2g). Stomata are found in this tissue (Fig. 2h). Likewise in the adaxial epidermis, the outer wall thickness is $1.3 \mu \mathrm{m}$.

\section{Morphological changes in leaves and developmental forms of the leaf miner}

Horse-chestnut leaf miner (Cameraria ohridella) moths were observed on tree trunks in the second half of April. The beginning of larvae feeding was associated with the appearance of claret coloured and orange spots (Fig. 3a,b) that covered the epidermal cells. These cells had dark red walls and an orange cytoplasm (Fig. 3c,d). This colour may indicate the presence of an increased amount of tannin compounds in the cells.

At the beginning of feeding, the plasmophagous larvae (instar L1) formed a narrow duct in the palisade parenchyma, which was visible both in the leaves viewed from above and in the cross-sectional view of the leaf blades (Figs 4a, 5a). Then, there were formed circular mines, which were seen from above as greenish and then brown spots that had a roundish shape, and characteristic rings meeting in the place where the insect had started feeding (Fig. 4a). As a result of further foraging, the spots became irregularly outlined (Figs 3e, 4f). The distribution pattern of the feeding places was uneven, and their number was within quite a wide range of $62-468$, on average 200 mines on the leaf surface.

The feeding places often merged together, occupying a large part of the leaf surface. An exception was the midrib area, to a certain degree free from tunnels eaten out by the larvae, since only in the apical parts of the leaves, where the main vascular bundle was much narrower, the larvae gnawed through the tissues beneath the upper epidermis and the mines merged. These vast mines were formed by histophagous larvae from the next instars (L2-L 4) (Fig.4b-e). Their body is flat and yellow coloured; it is composed of a prognathous head and over a dozen segments. The first segment is wider, while the last one much narrower than the other ones (Fig. 4e). The head is wedge-shaped, terminating with a chewing mouthpart. The legless larvae produce several setae in each segment. Brown striae occur on the dorsal part of the segments. Under the light mi- croscope, some systems were seen in the translucent body of the caterpillar, among others, the digestive and excretory systems (Fig. 4e).

After opening the mines, we observed exuviae remaining after earlier instar larvae and remnants of feces forming a black deposit (Fig. 4c). The larvae of the next larval instar (L5-L6), which were aphagous, did not take food. They wove the so-called summer cocoon - thin and translucent (Fig. 4g), in which pupae developed that gave a new generation of moths in the same year, or the so-called winter cocoon - diapausing, which is thickly woven and with a darker colour (Fig. 4h) and which the imago leaves the next year. The pupae were brown and reached a length of 3.5-4.5 mm (Fig. 4h). They had a spine on their head which was used to break through the cocoon and the upper epidermis of the leaf (Fig. 5h), thereby allowing the moth to get out of the cocoon, leaving behind an empty pupal case (exuvia) protruding outside (Fig. 4i).

\section{Damage to leaf tissues}

Young larvae of the horse-chestnut leaf miner, feeding on the liquid contents of the leaf, eat out passages (mines) in the palisade parenchyma, initially in the intercostal regions of the leaf. These passages are narrow and cover only a part of the parenchyma layer, and subsequently they are deepened (Fig. 5a). The parts of the palisade parenchyma cells adjacent to the epidermis gradually die and change their colour to brown (Fig. 5a-d). As a result of intensive feeding of the larvae, at some places only the epidermis remains in the upper part of the leaf, to which only small parts of the walls of the palisade parenchyma cells adjoin (Fig. 5e).

In the mines observed by us, tissue damage related not only to the palisade parenchyma, but also to the spongy parenchyma (Fig. 5d). Within the area of the mines, the horse-chestnut leaf miner larvae avoided both idioblasts with calcium oxalate crystals (Fig. $3 \mathrm{f}, \mathrm{g}$ ) and the cells containing tanning compounds or oils (Fig. 5c).

Initially, the patches beneath which the mines were located were visible only on the upper side of the leaf. At the end of the growing period, all the mesophyll tissues and the epidermis on both sides of the lamella were dying in the mine area as a result of larvae feeding. This resulted in the appearance of these patches also on the bottom side of the leaf; then, the necrotic parts of the leaves dropped off and the whole leaf blades fell off. 

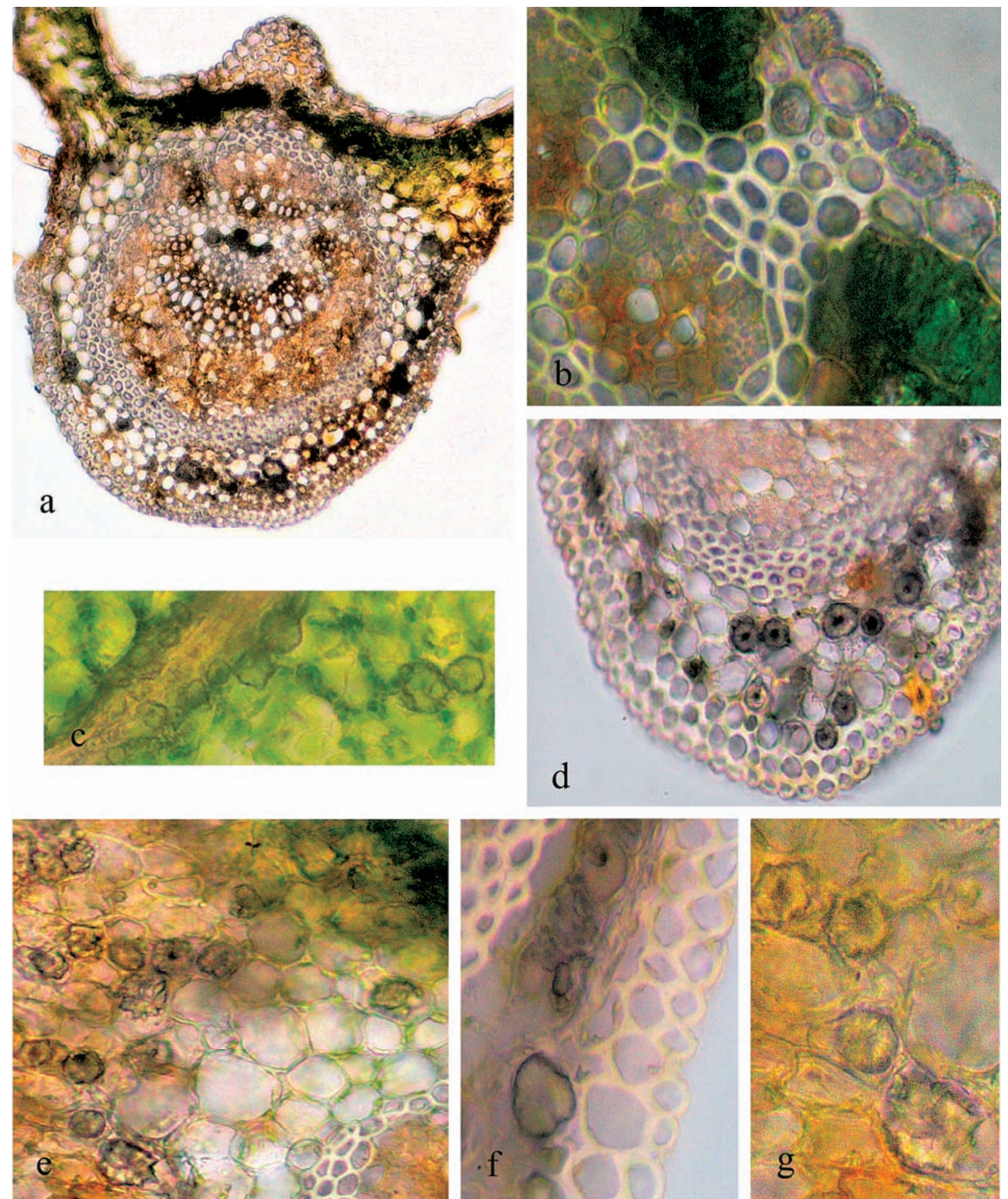

Fig. 1. Sections of leaf veins in common horse chestnut leaves. Leaf cross sections (a, b, d - g); Portion of a leaf blade with the vein from the bottom side of the leaf (c).

a - Tissues of the vein with a brown colour of the cell walls caused by the presence of tannins in the area of the vascular bundles and parenchyma.

$\mathrm{b}$ - Portion of the upper part of the vein with the visible vascular bundle, sclerenchyma and epidermis covered with a striated cuticle.

$\mathrm{c}$ - Different sized calcium oxalate crystals occurring in the parenchymal cells located along the vein.

$\mathrm{d}, \mathrm{e}, \mathrm{f}, \mathrm{g}-$ Calcium oxalate crystals occurring in the cells of the leaf vein.

$\mathrm{a}-\mathrm{x} 110 ; \mathrm{b}-\mathrm{x} 590 ; \mathrm{c}-\mathrm{x} 400 ; \mathrm{d}-\mathrm{x} 280 ; \mathrm{e}-\mathrm{x} 400 ; \mathrm{f}, \mathrm{g}-\mathrm{x} 560$. 

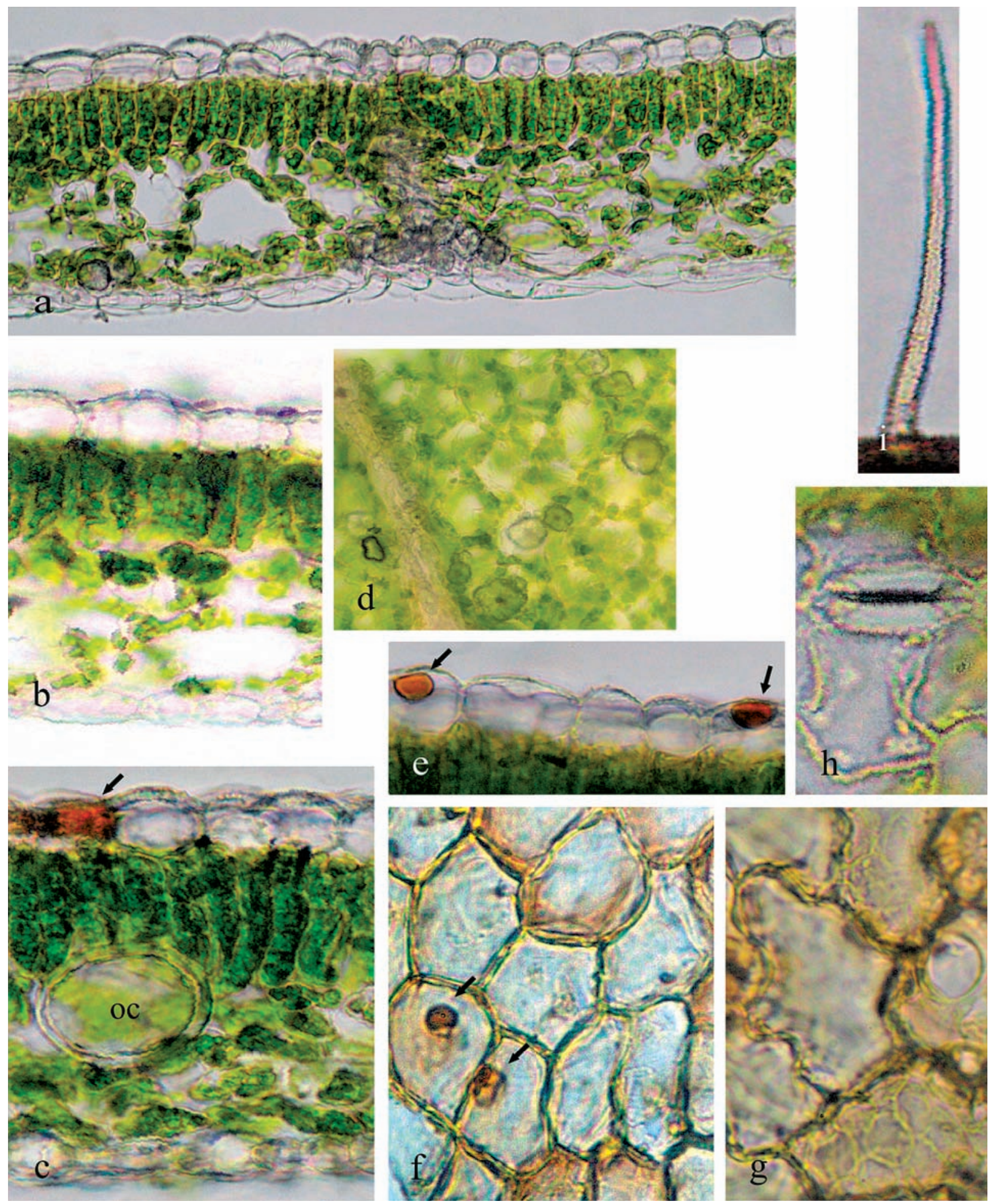

Fig. 2. Portions of leaf blades of common horse chestnut.

a, b, c - Leaf blade cross sections with visible druses (a), cells of the upper and lower epidermis (arrow), differing in size, and an oil cell (oc).

$\mathrm{d}$ - Druses visible in the spongy parenchyma of the leaf, viewed from the side of the lower epidermis.

e, f - Adaxial epidermal cells with tannins (arrows).

$\mathrm{g}, \mathrm{h}$ - Abaxial epidermal cells with the undulation of the anticlinal walls, a stoma visible $(\mathrm{h})$.

$\mathrm{i}$ - Non-glandular trichome from the leaf vein.

a, i - x 350; b - x 470; c, e, h-x 590; d - x 400; f - x 630; g - x 1000. 

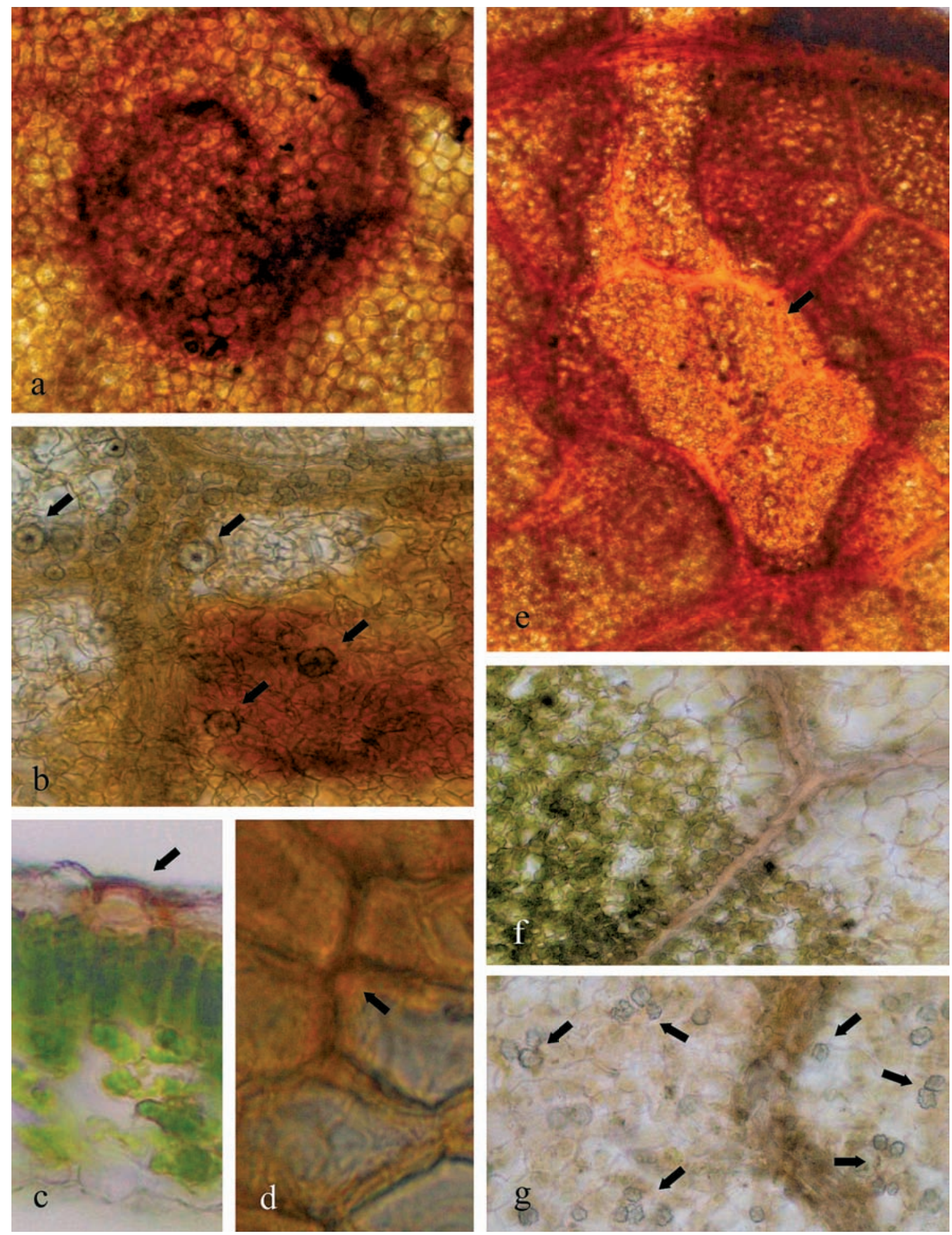

Fig. 3. Portions of leaf blades of common horse chestnut damaged by the horse-chestnut leaf miner.

a, $b$ - Red-brown spots formed as a result of the colouration of the upper epidermis in the places where the horse-chestnut leaf miner larvae fed (arrows). Druses can be seen along the veins and in the palisade parenchyma (arrows).

c, $\mathrm{d}$ - Epidermal cells in the vicinity of the places where the leaf miner fed, with coloured walls as a result of the presence of tannins (arrows).

e - Mine seen trough the tissues, visible on the upper side of the leaf.

f, $g$ - Boundaries of feeding of miner larvae, viewed from the side of the lower epidermis. Visible cells with calcium oxalate crystals left in the mine area (arrows).

$\mathrm{a}-\mathrm{x} 200 ; \mathrm{b}-\mathrm{x} 400 ; \mathrm{c}-\mathrm{x} 470 ; \mathrm{d}-\mathrm{x} 800 ; \mathrm{e}-\mathrm{x} 590 ; \mathrm{f}, \mathrm{g}-\mathrm{x} 260$. 

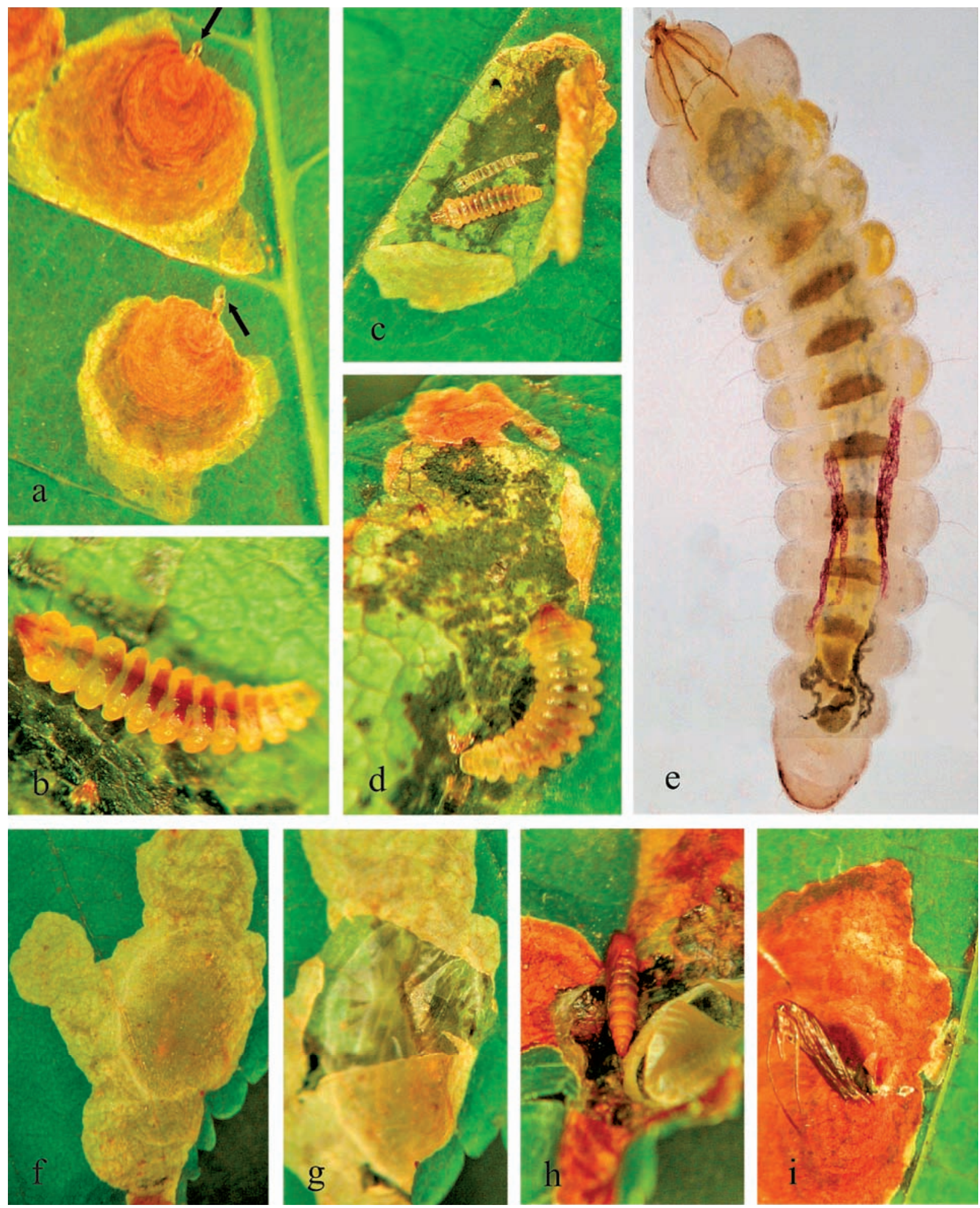

Fig. 4. Different developmental stages of Cameraria ohridella in the leaves of Aesculus hippocastanum.

$\mathrm{a}$ - Spots locating the mines formed at the beginning of larvae feeding.

$\mathrm{b}-\mathrm{e}$ - Caterpillar of the horse-chestnut leaf miner.

$\mathrm{f}, \mathrm{g}-$ Pupa cocoon visible in the area of the mines.

$\mathrm{h}$ - Pupa released after mechanical damage of the cocoon.

$\mathrm{i}$ - Case (exuvia) remaining after the moth got out.

a, c, f, h, i-x 5; b - x 12; d - x 8; e-x 55; g-x 7 . 

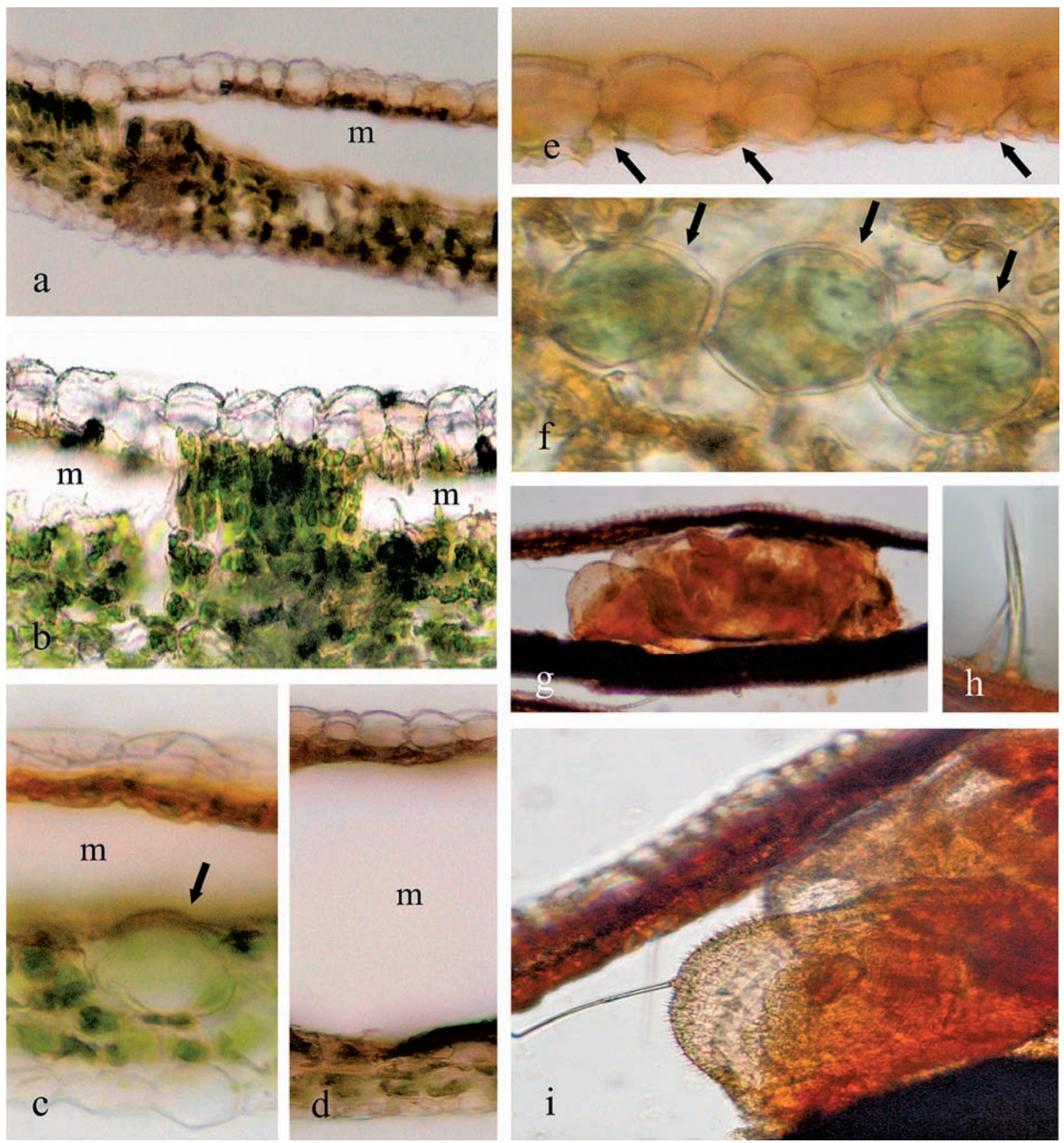

Fig. 5. Cross sections of common horse chestnut leaves with visible mines and a pupa of the horse-chestnut leaf miner.

$\mathrm{a}-\mathrm{d}$-Different sized mines $(\mathrm{m})$ in common horse chestnut leaves formed as a result of feeding of horse-chestnut leaf miner larvae, $\mathrm{c}$ - an oil cell (arrow) remaining outside the feeding zone.

e - Upper epidermis layer from the mine region with remnants of palisade parenchyma cells (arrows).

$\mathrm{f}$ - Oil cells (arrows), viewed from the lower side of the epidermis, left by the feeding larvae.

g, i - Pupa (g) and its magnified part (i).

$\mathrm{h}$ - Dagger-like appendage from the body of the pupa used to cut through the cocoon and leaf tissues.

$\mathrm{a}-\mathrm{x} 350 ; \mathrm{b}-\mathrm{x}$ 590; c - x 415; d - x 300; e - x 700; f - x 895; g - x 53; h-x 365; i - x 180.

\section{DISCUSSION}

Horse chestnut leaves, with thin leaf blades and a single-layered palisade parenchyma, represent the mesomorphic type of structure which is found in plants adapted to moderate light and moisture conditions. The outer cell walls of the adaxial and abaxial epidermis do not reach a large thickness and are covered by a relatively thin layer of cuticle, while the occurrence of non-glandular trichomes is limited to the bottom 
surfaces of the leaf veins. The mechanical tissues in these leaves are found only close to larger vascular bundles. In the case of horse chestnut leaves, it is not complicated for a phytophagous insect to overcome the outer mechanical barrier which comprises the upper epidermis and its products. In the leaves of this species, the palisade parenchyma layer, with its thin-walled cells containing a large amount of chloroplasts, is a valuable food easily accessible to an herbivore.

The occurrence of red and claret coloured spots, as a result of the change in the colour of the epidermis, was observed in the leaves attacked by the leaf miner. In the cells of this tissue, there were dark red coloured walls, vacuoles containing a brown substance, and an orange coloured cytoplasm, which may result from the presence of tannins. E s a u (1973) reports that tannins occur abundantly in the leaf tissues of many plants as well as in pathological outgrowths. In the cells, tannins can impregnate the cell walls, they are components of the vacuole or form fine droplets merged in the cytoplasm. One of the described functions of tannins is to protect plant cells against decay and damage by animals (Kopcewicz and Lewak, 1998; Leszczyński, 2001). Tannins are also treated as protective colloids maintaining the homogeneity of the cytoplasm (E s a u , 1973). Moreover, tannins may inhibit the activity of the enzymes which play an important role during insect feeding (L e s z c z y ń s k i, 2001).

Many studies have confirmed that specific secondary metabolites, among others, tannins, have an adverse effect on herbivores, being one of natural plant resistance factors. High concentrations of tannins in plant tissues cause great difficulties with digestion of plant food by insects ( $\mathrm{Zucker}$, 1983; E dwards, 1992; Leszczyński, 2001). The production of larger amounts of tannins is one of the strategies of physiological defence against phytophagous insects. Tannins are derivatives of phenolic compounds with a bitter taste and toxic properties that can discourage or deter animals from feeding (Kohl mún z e r, 1998; Kopcewicz and Lewak, 1998). The presence of catechin tannins has been found in the tissues of common horse chestnut (B r o d a , 2002). It can be presumed that the presence of large oil cells is also a natural protection of horse chestnut leaves against pest feeding. Evert (2006) reports that oil cells belong to the common types of secretory cells found in different families. These cells produce and accumulate oil. Their thick cell wall is composed of 3 layers and the middle layer contains suberin lamellae.

The poor activity of the physiological defence strategy, associated with the presence of tannins and oils in the horse chestnut leaves, can be attributable to the fact that the feeding leaf miner larvae avoid the tannin-containing tissues, i.e. the epidermis and the deeper located cells containing oil.
One of the mechanical barriers to insects can be calcium oxalate crystals; they were found in the horse chestnut leaves in the crystal-bearing cells forming clusters in the vicinity of the vascular bundles as well as in the cells dispersed in the subepidermal mesophyll. These crystals may be used by the plant to fight against phytophagous insects and to cause damage to their bodies ( $\mathrm{S}$ a w id is et al. 2005). However, our observations show that the leaf miner larvae avoided the cells with calcium oxalate crystals which remained next to the epidermis layer, outside the feeding place. According to other authors, calcium oxalate crystals produced in the cells of higher plants can not only be a form of defence against animals, but they also have an effect on the strengthening of the plant structure and are a place of calcium storage ( $\mathrm{N}$ a k a t a , 2003; Franceschi and Nakata, 2005).

\section{CONCLUSIONS}

Leaf miner larvae foraging on common horse chestnut leaves initially feed on the palisade parenchyma tissues, and then on the spongy parenchyma, which leads to the death of the epidermis on both sides of the leaves and then to drying of the leaf blades.

In horse chestnut leaves, there are both physiological and mechanical barriers that can protect the plant tissues against feeding of phytophagous insects, but they are not sufficiently effective. These barriers include the following elements: calcium oxalate crystals, cells with tannins in the epidermis, and oil cells in the parenchyma.

During feeding, leaf miner larvae avoid vascular bundles, tanning-containing epidermal cells, idioblasts with calcium oxalate crystals, and oil cells.

\section{REFERENCES}

Antkowiak L., 1998. Rośliny lecznicze. Wydawnictwo Akademii Rolniczej im. Augusta Cieszkowskiego w Poznaniu. Poznań. (in Polish)

B a ranowski T., 2004. Attempts to limit harmfulness of the horse chestnut leaf miner (Cameraria ohridella). Prot. Collect. Against Pests and Dis. 2: 18-22.

Baranowski T., Parus A., Fajfer B., 2002. Występowanie szrotówka kasztanowcowiaczka (Cameraria ohridella Deschka \& Dimić) na kasztanowcach w Poznaniu w latach 2000-2001. / The occurrence of the horse-chestnut leaf miner (Cameraria ohridella Deschka \& Dimić) on horse chestnut trees in Poznań in the period 2000-2001. Progress In Plant Protection/ Postępy w Ochronie Roślin, 42: 654-657. (in Polish)

B rod a B ., 2002. Zarys botaniki farmaceutycznej. Państwowy Zakład Wydawnictw Lekarskich. Warszawa. (in Polish)

Edwards P.J., 1992. Resistance and defense: the role of secondary plant substances. Pest and Pathogens Plant Responses to Foliar Attack. BIOS Sci. Publ. 69-84. 
E s a u K., 1973. Anatomia roślin. Państwowe Wydawnictwo Rolnicze i Leśne, Warszawa. (in Polish)

Evert R.F., 2006. Esau's Plant Anatomy. Willey - Interscience. New Jersey.

Feemers M., 1997. Versuche zur Bekämfung von Cameraria ohridella Deschkast Dimic mittels Stamminjection (Präparat: Confidor). Forestschuts Aktuell, 21: 24-25 (in German)

Franceschi V.R., Nakata P.A., 2005. Calcium oxalate in plants: formation and function. Ann. Rev. Plant Biol. 56: 41-71.

Głowacka B., Lipiński S., Tarwacki G., 2009. Możliwości ochrony kasztanowca zwyczajnego Aesculus hippocastanum L. przed szrotówkiem kasztanowcowiaczkiem Cameraria ohridella Deschka et Dimic. I Possibilities to protect common horse chestnut (Aesculus hippocastanum L.) against the horse-chestnut leaf miner (Cameraria ohridella Deschka et Dimic.). Leśne Prace Badawcze, 70 (4): 317-328. (in Polish)

Grabenweger G., 2003. Parasitism of different larval stages of Cameraria ohridella. BioControl, 48:671-684.

Grabenweger G., Avtzis N., Girardoz S., Hrasovec B., Tomov R., Kenis M., 2005. Parasitism of Cameraria ohridella (Lepidoptera, Gracillariidae) in natural and artificial horse - chestnut stands in the Balkans. Agri. Forest Entom. 7:291-296.

Jędrzejko K., Kowalczyk B., Bacler B., 2007. Rośliny kosmetyczne. Wydawnictwo Śląskiego Uniwersytetu Medycznego. Katowice. (in Polish)

Kohl mún zer S ., 1998. Farmakognozja. Wydawnictwo Lekarskie. Warszawa. (in Polish)

Kopcewicz J., Lewak S., 1998. Fizjologia roślin. Państwowe Wydawnictwo Naukowe. Warszawa. (in Polish)

Kosibowicz M., 2005. Szrotówek kasztanowcowiaczek Cameraria ohridella Deschka \& Dimmić (Lepidoptera, Gracillaridae), nowy inwazyjny szkodnik kasztanowca białego Aesculus hippocastanum L. w Polsce - biologia i metody zwalczania. / The horse-chestnut leaf miner Cameraria ohridella Deschka et Dimic. (Lepidoptera, Gracillaridae), a new invasive pest of white horse chestnut (Aesculus hippocastanum L.) in Poland - biology and control methods. Leśne Prace Badawcze, 2:121132. (in Polish)

Krehan H., 1997. Horse chestnut mining moth - a comparison of control methods. Forstschuts - Aktuell, 19-21: 2-7.

Kukuła A., Hurdej M., Mazurek J., 2002. Rozwój szrotówka kasztanowcowiaczka (Cameraria ohridella Deschka \& Dimić) na terenie miasta Wrocławia i próby ograniczenia jego liczebności. / The development of the horse-chestnut leaf miner (Cameraria ohridella Deschka \& Dimić) within the city of Wrocław and attempts to reduce its numbers Progress in Plant Protection / Postępy w Ochr. Rośl. 42(2).

Leszczyński B ., 2001. Naturalna odporność roślin na szkodniki. [In:] Biochemiczne oddziaływania środowiska. Akademia Medyczna. Lublin, (in Polish).

Li piński M ., 2010. Pożytki pszczelarskie. Państwowe Wydawnictwo Rolnicze i Leśne. Warszawa, (in Polish)

Łabanowski G., 2003. O szrotówku kasztanowcowiaczku na VII Europejskim Kongresie Entomologicznym. Ochrona Roślin, 4/2003, (in Polish)

Łabanowski G., Soika G., 1998. Szrotówek kasztanowcowiaczek zagraża kasztanowcom w Polsce / The horse-chestnut leaf miner threatens horse chestnut trees in Poland. Ochrona Roślin 12: 12 (in Polish)

Łabanowski G., Soika G., Chałańska A., Maciejewska-Stefańska U., 2004. Ochrona kasztanowca białego przed szrotówkiem kasztanowcowiaczkiem (Cameraria ohridella Deschka \& Dimić). / Protection of white horse chestnut against the horse-chestnut leaf miner (Cameraria ohridella Deschka \& Dimić). Progress In Plant Protection / Postępy Ochr. Rośl. 44 (1), (in Polish)

Nakat a P. A., 2003. Advances in our understanding of calcium oxalate cristal formation and function in plants. Plant Sci. 164: 901-909.

Nardini A., Raimondo F., Scimone M., Sallco S ., 2004. Impact of the leaf miner Cameraria ohridella on whole - plant photosynthetic productivity of Aesculus hippocastanum: insights from model. Trees, 18: 714-721.

Podbielkowski Z., 1992. Rośliny użytkowe. Wydawnictwa Szkolne i Pedagogiczne. Warszawa, (in Polish)

Podbielkowski Z., Sudnik-Wójcikowska B., 2003. Słownik roślin użytkowych. Państwowe Wydawnictwo Rolnicze i Leśne. Warszawa, (in Polish)

Sadowska A., 2004. Rakotwórcze i trujące substancje roślinne. Wydawnictwo SGGW. Warszawa, (in Polish)

Sawidis T., Kalyba S., Delivopoulos S., 2005. The root - tuber anatomy of Asphodelus aestivus. Flora, 200: $332-338$.

Seneta W., Dolatowski J., 2007. Dendrologia. Państwowe Wydawnictwo Naukowe. Warszawa, (in Polish)

Skuhravy V., 1999. Zusammenfassende Betrachtung der Kenntnisse uber die Rosskastanienminermotte, Cameraria ohridella Desch. \& Dim. (Lep. Lithocolletidae), Anzeiger f. Schadlingskunde, 72:95-99, (in German)

Strzelecka H., Kowalski J., 2000. Encyklopedia zielarstwa i ziołolecznictwa. Państwowe Wydawnictwo Naukowe. Warszawa, (in Polish)

Zucker W.V., 1983. Tannins: Does the structure determine function? An ecological perspective, Am. Nat. 121: 335-365. 


\section{Zmiany w tkankach liści kasztanowca zwyczajnego (Aesculus hippocastanum L.) zasiedlonych przez szrotówka kasztanowcowiaczka (Cameraria ochridella Deschka\&Dimić)}

W latach 2010-2011 przeprowadzono obserwacje morfologiczne i badania anatomiczne liści kasztanowca zwyczajnego (Aesculus hippocastanum L.) z oznakami uszkodzeń spowodowanymi żerowaniem larw szrotówka kasztanowcowiaczka (Cameraria ohridella Deschka\&Dimić). Liście pobierano z drzew rosnących na terenie Lublina (Poland). Preparaty mikroskopowe wykonano ze świeżego i utrwalonego materiału roślinnego. W mikroskopie świetlnym analizowano cechy anatomiczne liścia w celu określenia bariery mechanicznej dla żerujących szkodników. Obserwowano również zmiany w czasie postępujących uszkodzeń tkanek liści przez larwy. Przedstawiono wybrane stadia rozwojowe szkodnika. Wykazano, że bardzo cienkie blaszki mezomorficznych liści Aesculus hippocastanum wytwarzają słabo rozwiniętą barierę mechaniczną, do której możemy zaliczyć obecność kolenchymy, idioblastów z druzami szczawianu wapnia, nieliczne włoski mechaniczne występujące przy nerwach oraz stosunkowo cienkie ściany zewnętrzne komórek epidermy. Barierę fizjologiczną mogą tworzyć komórki zawierające garbniki oraz występujące w mezofilu komórki olejkowe. Jednakże żerujące larwy szrotówka żywią się tylko komórkami parenchymy palisadowej i gąbczastej, pozostawiając nieuszkodzone komórki z garbnikami oraz idioblasty z kryształami szczawianu wapnia oraz olejkami. Postępujące żerowanie szkodnika w mezofilu liścia doprowadza do obumierania epidermy po obu stronach blaszki liściowej i zasychania fragmentów liści w obrębie min. 
